\title{
THE STUDITE ANTHROPOLOGY IN THE MISSIONARY CONTEXT OF ICONOLOGY
}

\author{
Mihai HIMCINSCHI *
}

\begin{abstract}
Mankind has wanted, from the beginning of times, to free the human face completely from any materiality, to be like God (Genesis 3:5). This desire is fulfilled completely through Incarnation, when the Son of God, born Human, succeeded to give to the humanity an inner strength capable of transforming the face made from dust, so the divine created and uncreated energies can rest inside it. According to the Orthodox anthropology, the face of God in the human being is rebuilt, changed and transformed in God in grace.

The novelty of the present study resides first in the fact that offers, for the first time in the Romanian Orthodox missionary theology, an iconic synthesis based on an anthropological missionary fundament, placing the work of Saint Theodor the Studite (759-826) in the centre of the scientific research. Secondly, our analysis is contemporary, appealing, and interesting because it fortifies the iconological mission of the Orthodox Church in the contemporary society and places on a level of axiological equality The Word of God, meaning the Gospel, and the Image/Icon, meaning His divine-human Face, a perspective that is absolutely odd for the Protestant world, even after 500 years after the Reform from 1517. The study opens the door for a possible inter-confessional dialogue on the theme of the divine theophanies.
\end{abstract}

Keywords: iconography, mission, anthropology, grace, deification, dialogue, image, idol, ecumenism, monasticism

PhD, Rev. Professor, Faculty of Orthodox Theology at "1 Decembrie 1918" University in Alba Iulia. 


\section{Preliminaries}

The humans have dreamt, from the beginning of their existence, to clear their face of any trace of materiality, to be like God - The Holy Trinity (Genesis, 3:5), because they were created after the icon/image and likeness of God (Genesis 1:26). In an anticipated manner, this was mysteriously achieved through Incarnation and observable in Transfiguration, when the Son succeeded to impress to His humanity an inner side capable to sophianise the face of dust, to make it completely transparent to the divine created and uncreated energies. Then, through Resurrection, Ascension and Sitting at the right hand of the Throne, mankind is completely deified, becoming the Iconic prototype of the humanity.

Thus, the iconological fundament of the Church has a trinitarian, Christological and anthropological basis: trinitarian because the Son is the Icon (Image) of the Father (Hebrews 1:3); Christological because Christ is the Son of the Father in our image (Philippians 2:7) and anthropological due to the divine act of the human creation (Genesis 1:26) after the structural pattern of the Trinitarian - Hypostatic Love.

Trinitarian: As a three hypostatic dynamic reality, the Father resides His Ghost in His Son, a Ghost that shines inside Him, and the light returns to the Father as a sign of love from the Son. This dogma, beside the personal character of God and the discovery of the God as Love, shows that there is an interpersonal relation in God, which cannot be confounded with the Persons and unites Them distinctly. The Father, through the divine birth, brings His Son in front of Him as His Self/ Face, in a total giving. But the Father remains the Father and the Son remains the Son, although the Son affirms the Father as eternal continuous Father, because the Son gives Himself to the Father.

It is a reciprocal affirmation (of the Father through the Son/ Image and of the Son/Image through the Father), but a distinctive one in the same time. Love unites but, paradoxically, does not confound the Birth-Giver with His Image. In the same way, the Ghost coming from the Father, affirms the Father through the Son and the Son affirms the Father through the Ghost. All these acts are entirely personal, distinctive and unmistakable, although all the Persons are 
active together in Their Being. Although coming only from the Father, in the Son in Whom He resides and shines, the Holy Ghost is active as well as the Son born from the Father and Who is not passive toward Him and, receiving the Ghost as a total giving of the Father, keeps Him inside as a sign/icon of the joy of receiving and shines the luminous Image of the Father.

Christological: Under a Christological aspect, the Logos or the Word of God, in which the Holy Ghost rests eternally, through the Incarnation, gave to the creatures their meaning and reasoning, the iconological model by sharing them life in His Ghost. The meaning/model of all the reasons of the things is the Reason or the Logos of the Father, the more so as the human has reasoning and life, reason coming from the Divine Logos and life from the Holy Ghost resting in Him, making the human Their icon. The value of the reasons and of the meaning of things is revealed only in our communion with God, our supreme Model or Icon. The Holy Ghost rests and shines in Christ, the Son of the Incarnated God, so He is present inside us through His uncreated energies. Our life becomes an iconic life, united in the Holy Ghost with the life of Christ.

Anthropological: The human as a person is mystery, an apophatic existence in the being, an irreducible personal existence, because it lives in a communion opened to dialogue and relation. The human person, through the Word of God, is also led through the Holy Ghost to the final aim, which is the Holy Trinity. The Holy Ghost puts the human being in connection, through the Son of God made human, with the life in the divine community. It is the only way the human can experience the connection with the Holy Trinity as Her image. The Father is mirrored in our mind, the Son is present in our consciousness and the Holy Ghost is present in the communion with our fellow beings. Thus, the human being is trinitarian-iconic inside and can remain in a life communion with God and the other human beings, because its iconicity involves all the other people, impossible to live without, and, in the same time, the relation with the Trinitarian God, where the Persons have an interpersonal, or inter-subjective and perichoretic life, representing the structure of a complete existence and an iconological model for our way of being. 


\section{Saint Theodor the Studite - the Orthodox synthesis of the iconology}

The icon represents deliverance in an idolatrous world and confession for all the saints along the centuries. The idolatry is present in our society, which is losing the Image of God, the reality of His presence into the world and inside His chosen ones. Living the experience of the iconoclastic campaign, Saint Theodor affirmed: "we, the meek, are living the burden and the life of the saints..., because our image means that..., in order to be delivered through obedience. The holy icons are proof to us for this deliverance and we are exiled from our monastery for our devotion to the holy icons"1.

In 1926, 1100 years after the death of Saint Theodor the Studite, a group of theologians gathered to the Monastery Saint-Tryphon of Touzla considered the saint and his work to be "a fervent defender of the truth, the pillar and the supporter of the Orthodox faith, the inspired guide of the Orthodoxy, the blaze of the universe, illuminating all the believers through teachings"'.

Although his work was centred on the fight against iconoclasm, defending first of all the image of Christ, as effect of the Incarnation, his doctrinarian interests also have a Marian side. For Saint Theodor the Studite, some hymns dedicated to Virgin Mary in the pages of the Triodyon (a theme that requires deep research, as Marian base of the Studite iconology) are the expressions of a doctrinarian language focused on the eternal virginity of Mary, the divine maternity and the universal mediation as the Theotokos, Mother of the Prototype. On this theme, a special attention must be given to the saint's speeches for the Marian celebration: The Nativity of Mary ( $8^{\text {th }}$ of September), The Dormition of the Mother of God (15 $5^{\text {th }}$ of August), The Presentation of Mary (2 $1^{\text {st }}$ of November), The Presentation of Jesus ( $2^{\text {nd }}$ of February) and The Annunciation (the $25^{\text {th }}$ of March), or with the occasion of catechesis addressed to the young people. The Mother of God is the sky

${ }^{1}$ ST. TheOdore the STUdite, "Cuvântul 42, La Duminica fiului risipitor: despre înfrânare şi despre întărire în mărturisirea sfintelor icoane”, in Cuvântări duhovnicești, trad. Filaret al Râmnicului, $2^{\text {nd }}$ ed. Alba Iulia, Reîntregirea, 2016, p. 164.

2 Martin JugIE, "La doctrine mariale de saint Théodore Studite", in Échos d'Orient, tome 25, no. 144/1926, p. 421. 
where the Sun of justice shines, the land that gives the fruit of life and the sea that gives birth to the spiritual Pearl.

As iconological-doctrinarian fundament, Saint Theodor the Studite uses often the motifs, the means and the consequences of the Incomprehensible One. Who does not admit the idea of comprehension, to an economical divine level, also does not admit the idea of image/icon/face, because the image/icon/face is contoured in the human mind only as a result of a delimitation of a hypostatic being as concrete entity of a well-defined process. "Not only Christ, but the entire universe disappears if there is no more any circumscription or any image" 3 .

The dogma becomes confession and the confession becomes martyrdom. The Holy Fathers took the economy to the level of concrete life, of image, articulating simultaneously these two fundamental elements of any religious system: the transcendence and the immanence. The Orthodox anthropological dynamism, difficult to be understood or dogmatised, falls in the disgrace of the anthropological dynamism of philosophical origins at the middle of the $8^{\text {th }}$ century, leading to the creation of resistance monachal centres around some theologians and saints. No treatises of abstract theologies were needed. It was needed a confirmation of the dogmatic truth through their own martyrdom. "Where are those speaking of not taking into account the martyrdom of dying for the icon of Christ? ...there are martyrs, worthy of the shiny crown given after death to those not renouncing to the icon of Christ, our Lord. But the iconomachs, dark as they are, want to attract others, too, in the depth of the perdition" . The conclusions were proportionate: "from now on, we should not dishonour with lying, abominating and empty words the lips sanctified by kissing the Holy Cross, nor the eyes illuminated by the sight of the holy wood"5; "we should think of the human nature. Let's remember the grace of the Heaven and the divine dignity given when made after the image of God and the shine in which

${ }^{3}$ ST. NichIFOR (The Patriarch), Antiretice, I, P. G. 100, 244 D.

${ }^{4}$ St. TheOdore the STUdite, „Cuvântul 55, În Duminica a treia a postului: despre creștinii bulgari, care au îndurat chinuri de mucenici, pentru că n-au vrut să mănânce carne în postul mare", in op. cit., p. 202-203.

5 IDEM, "Cuvântul 86, La Înălțarea Crucii: despre înșelăciunea dulceții păcatului și despre căderea în patimi necinstite”, op. cit., p. 301. 
Christ appeared at His Resurrection God"6.

\section{A Studite conclusion: Christ and His icon are simultaneous presences}

Among the adversaries of the iconoclasm, the most well-known is Saint John the Damascene, who established the most important directions of the Orthodox iconology: "the role and the utility of the holy images, their dedication and honouring, as well the essential relativity of the cult of the (holy) images"7. The post-Damascene period was not spared by new iconoclast subtleties and objections on the nature of the iconic cult.

Saint Theodor the Studite, compared to Saint John the Damascene, dedicated his entire life to defending the cult of the holy icons, separating the theological perspective of the visual in type and Prototype.

"The Prototype and the icon are one in their similarity to the hypostasis but two in their nature, not as a single thing divided through two similarities, with no communion and relation between them and not as a single thing called with two different names - the prototype called icon one time and the icon called prototype another time. The prototype is always called prototype and the icon is called icon; they do not transform one into another". 8

They both deserve the same dedication due to the identity of the hypostatic resemblance and due to the potential existence of the icon in the prototype before the hypostasis. "The icon of Christ is in Him as the One with a human form; when we see it included in several ways in materiality, we celebrate more His greatness"'.

Any image carries inside the likeness to the prototype: "the

${ }^{6}$ IDEM, “Cuvântul 90, În Duminica a patra după Înălțarea Crucii: să nu rătăcească mintea noastră în cele necurate, că să privească frumusețile negrăite ale zidirii lui Dumnezeu", op. cit., p. 313.

7 Venance GRUMEL, 'L'Iconologie de saint Théodore Studite", in Échos d'Orient, no.123/1921. p. 257.

${ }^{8}$ St. TheOdORE THE Studite, Iisus Hristos Prototip al icoanei Sale, trad. Ioan I. Ică jr., Alba Iulia, Deisis Publishing House, 1994, p. 159.

${ }^{9}$ Ibidem, p. 163. 
honour given to the image passes to the prototype" 10 . The prototype is perfect, the type is similar. The difference between them is ontological. E.g., Christos, as Man, is identical to the Father through Deification, identical to the Holy Virgin and with all of us through humanism. As Human, He is the divine Prototype of the Divine Grace, through the human nature, in economical relation to the world. "The icon is a pure relational reality, exterior to the prototype, founded not on the participation to the prototype, but on a hypostatic similarity to it. There is difference and also identity between icon and prototype: difference in substance and identity in hypostatic similarity" "The essence of the iconic representation resides in the fact that it represents the hypostasis and not the nature of the represented issue. The nature may be contemplated only through the hypostasis, which outlines it and in which it subsists. Christ and His icon must be given the same dedication due to the identity of hypostatic resemblance and not due to the being or to the nature, which differ in its inferiority from type to Prototype.

The type and the Prototype are distinctive, different in their nature, not necessarily in their personal character, which may be common. On the contrary, there is a pregnant difference, almost conflictual, between image and sign or symbol. The icon is always the image of a rational hypostasis, while the symbol may express only an impersonal nature. "Unlike the sign or the symbol, the image is the place of the appearance (epiphany) of a personal presence. If the symbol may be manipulated and used as instrument in the behalf of another presence, the image is its own symbol, its own presence and representative - not manipulable"12.

The Saviour has double co-substantiality (with the Father as God, with the Virgin and with us as Human). Christ has two natures; the human nature is hypostasised in the Hypostasis of the eternal Logos of the Father, so His icon represents the Hypostasis of the divine Son.

10 St. BASIL THE GREAT, "Despre Sfântul Duh", trad. C. Cornițescu and T. Bodogae, in Părinți și Scriitori Bisericești, vol. 12, București, Institutul Biblic și de Misiune al Bisericii Ortodoxe Române, 1988, p. 60.

11 Ioan I. ICĂ, "Iconologia bizantină între politică imperială și sfințenie monahală”, in ST. Theodore the Studite, Iisus Hristos Prototip al icoanei Sale, Alba Iulia, Deisis, 1994, p. 27.

12 Ibidem, p. 18. 
"Substantially different, as heterogeneous natures, the prototype and the image have hypostatic identity based on their formal resemblance. Christ and His Icon have the same Hypostasis. There is a real presence of Christ in His Icon, one of hypostatic nature, more precisely a relational one. The icon is in Christ, not through hypostatic union, but as relation, based on their formal likeness (attested also by the inscription of the Name)"13.

The slave of the Prototype is not cleaved in His icon, because

"the icon is similar to the archetype: the natural icon in a natural way and the artificial one in an artificial way. But one is identical suddenly in being and the resemblance with the seal it represents, as Christ in divinity with His Father and in humanity with His mother. The other, identical in resemblance, is strange from the being of the archetype as the icon of Christ to Christ. As a result, there is an artificial icon of Christ that receives His likeness". ${ }^{14}$

Because there are not two dedications - of the Father and of the Son, united divinely, there are not two hypostatical successive dedications to Christ and to His icon because there is the One and the same divine-human Hypostasis through the unity of the resemblance, even though there are two ontological or natural realities: the deified human nature, escribed to the Incarnated Logos and the nature of the created element of the iconic representation, identic to the prototype, even if different ${ }^{15}$.

In the above described aspects, Saint Basil the Great strengthens, as early as the $4^{\text {th }}$ century, the indestructible connection between the Father and His Son as His Image, between the type and the Prototype, between the Hypostatic Being and the Grace, between Christ and His icon realised technically in several manners:

"by adoring the God in God, we confess the specificity of the hypostases and we remain to the belief in one God; we consider that there is a single image in God the Father and God the Son, reflecting the

${ }^{13}$ Ibidem, p. 41.

${ }^{14}$ ST. TheOdORE THE STUdiTE, op. cit., p. 151.

15 ST. GRIGORY OF NYSSA, "Epistola către fratele său, Petru: Despre diferența dintre ființă și ipostas", in St. THEOdORE THE STUDiTE, Iisus Hristos Prototip al icoanei Sale, rom. trans. Ioan I. Ică jr., Alba Iulia, Deisis, 1994, p. 207. 
immutability of the divinity. The Son exists in the Father and there is the same face in God the Son, because This is like That, and That is like This, thus the two of them are one. Seen as specificity of the persons, they are one and one, but after the identity of the nature, the two are one. So, how, if there are one and one, there are not two Gods? The face of the king is called king, but we do not have two kings. Neither the power, nor the grace is split. As we are under a single authority, the grace we receive is only one, because the dedication to the face passes to the prototype. Thus, the face is here through imitation. The resemblance between the technically realised faces is just as form, but, in the divine and simple nature, the unity resides in the participation to the divinity" ${ }^{16}$.

As, in the triadology, the personal characteristics do not split the divinity, in the same way, in iconology, the properties of the natures, type and prototype do not split the divine-human Hypostasis of Jesus Christ.

\section{The theophany of the face in a contemporary Athonite paradigm}

The Taboric pursuit or the transfiguration is the highest pursuit for the human being. "Thus, the will of the human for returning to the original justice and state is intertwined with the desire to live the light"17.

According to the Orthodox anthropology, the face of God in humans is rebuilt, changed and transformed in divine in grace.

"The humans, especially those cast away by various spiritual tendencies, various mystical currents of our times, or youthful enthusiasm and philosophical aspirations, hide deep in their soul the same Taboric pursuit and search for the uncreated light. God is not light in His essence, but after the work, related to the world, with His energetic presence into the world" 18 .

Thus, we understand why, in His icon, the Saviour does not circumscribe the uncircumscribed Divinity, but circumscribes naturally and kenotic through incarnation His icon and the Hypostasis, becoming

\footnotetext{
16 St. BASIL THE GREAT, op. cit., p. 60.

${ }^{17}$ Emilianos Simonopetritul, Cuvântări mistagogice la sărbători, rom. transl. By Agapie Corbu, Arad, Sfầntul Nectarie Publishing House, 2016, p. 210.

${ }^{18}$ Ibidem.
} 
one and the same reality, although his reality in the icon is a relational reality. The divine remains indescribable and incomprehensible, but not separated from the human nature of the unique Hypostasis of the Saviour. The Mystery of the incarnation is great (I Timothy 3:16), thus, Our Lord Jesus Christ may be iconically represented. The icon does not belong to theology; it belongs to the economy of the revealed God.

Through grace, the face of the human ascends to the Prototype. Per se, this face full of grace is painted and honoured in the icons of the Church with a missionary and confessing aim. In this icon, the human life is conjugated with the divine life. "The human body is not separated from his cleanest eternal part, and God, recognising His image in the human being, makes the man entirely divine. Nothing remains unassimilated by God"19. The human nature has an iconic and personal character and not through the insufficiency of the mental contemplation of Christ in us, but through the big honour given to the humans by God, in which the indescribable and the immaterial one is dressed in our created nature, as a vestment assumed in the Hypostasis of the Logos: unmixed, unchanged, undivided and unseparated.

The connection between type and Prototype resides in the capacity of the first to receive the light of the last, thus expressing an inferior form of the Model Per Se. There is no scission between God and His grace and there is no scission between the reproducing copy and the prototype. God created the man with the capacity for openness, for an ontological dilatation for the purpose of illumination. Although created materiality or dust (Genesis 2:7), the human was not created only for receiving grace, but, through the Mother of God, proved to be capable of receiving the Hypostasis of the Divine Logos, the son of the Father without beginning, as a start for our deliverance. The descent of the Personal God in humanity is a unique and unrepeatable act and, in the same time, the clear proof for the love of God for the world and also a proof for the possibility of cohabitation between the created and the uncreated. "After centuries of fight, the enthusiasm reigns in our Church, because it is the only one that kept the meaning of the uncreated work of God and the only one capable of receiving God"20, to accept

\footnotetext{
${ }^{19}$ Ibidem, p. 214.

${ }^{20}$ Ibidem, p. 250.
} 
Him as a personal reality for all the human senses: vision, audition, touch, etc.

The illumination of God in creation does not spend it and does not change it. As the rays of Sun do not empty the Sun of content, the shine of the Slave does not empty the creation. The divine theophanies do not impoverish the Being, they express it in the multitude of the economical meanings of the hypostasis, transforming and filling our existence, which also is hypostatic. "Gathering for the religious service, especially receiving the sacrament of Christ through the Holy Body and Blood, as well calling His name are necessary for theophany, with the meaning of vision, knowledge and consciousness" 21 .

In the divine Revelation, the holy images, in general, and the theophanies, in particular, were the most fascinating moments in the history of the deliverance because they complete the entire communication between God and man, without the pretention of comprehending the divine reality represented by them. The icon belongs to the revelation of the mystery of God Image received in the flesh (I Timothy 3:16). Not only in the ancient times, also in postmodernism, has the image had precedence over Word. This explains the fact that the old religions were idolatrous. In a different manner, the word has precedence over image in Judaism. For the Christians, the Word becomes flesh and the icon becomes a memorial of the Incarnation and, from a missionary point of view, equals the identity between the icon and the oral teaching of the Gospel.

If the Son of God wouldn't have taken the entire humanity in complete deification, the manifestation of the celestial power could not have been achieved completely. In an uncomplete humanity, the Logos could not be expressed completely. This inadvertence was speculated by the Protestants who always see the Word as hidden in His economical manifestations and refuse to speak of the vision on grace of the divine unseen in the Being. But what does it mean a pillar of cloud? (Exodus 13:21)? In fact, the pillar of cloud means the divine light, a light with a nature that makes it unsupportable by humans to see, seen by them only as darkness. It means the covering of God. The body of God is a cloud $^{22}$.

${ }^{21}$ Ibidem, p. 222.

${ }^{22}$ Ibidem, p. 223. 
Is the incarnated Son of God accessible (also) through icon? Is the icon a theophany observable by anyone? In the divine-human Person of the of our Saviour Jesus Christ, the entire humanity was liberated by passion and steadiness, which liberate too the other forms of theophany, expressed mandatory through the elements of the created world: cloud, pillar of fire, pile, dew, bread and Eucharistic wine, the word of the Gospel, His icon, etc.

"The light hides under a cloud due to our incapacity, because the cloud hides the kingdom of God inside us. The light grows dim - so happens with the body of God in front of the apostles - and becomes a cloud because, on one hand, spares us from responsibility and being guilty for the process and, on the other hand, gives us the possibility to live, due to the fact that seeing God without having repentance would kill us. If He hides, we may sometime repent and search for Him", ${ }^{23}$

Refusing to see the Grace leads to idolatry (Exodus 32:1-6). We must love our daily reality, our unrequired cloud, the unrequired darkness of our soul. Our unrequired Cloud is filled with the grace of God; it is the cloud covering the light of $\mathrm{Christ}^{24}$.

The iconic anthropology is the discovery of a new reality. "Each human is the image of God and you may not dedicate to the icon of God and mock in the same time the person of your brother" 25 . We see the divine grace and the grace of the deified human nature in the Prototype of the icon. On Mount Sinai (Exodus 33:23),

"God appeared in His human form, as prefiguration, in a prophetical preparatory manner. He showed Himself, a certain appearance of Him we use the word appearance $(\varepsilon \mu \varphi \alpha \sigma i \varsigma)$ because every word may be explained heretically - known and understood by all humans. God imitated a human thing to announce the coming of Christ. Moses saw only the back of God, nit the light of God. The light was hiding under the form of a cloud, of a pillar of fire, of the angels, of the pile and many other things. But when did Moses see the light? Moses saw the face of God on the Mount of Tabor. He saw the light when the grace appeared. Now, for the first time, the things are getting clear and it is discovered

${ }^{23}$ Ibidem, p. 226.

${ }^{24}$ Ibidem, p. 231.

${ }^{25}$ Ibidem, p. 226. 
that the light is God and God is light and the light exists also in darkness and blindness". ${ }^{26}$

\section{Conclusions}

There is an obvious connection between the written Word of the Holy Gospel and the painted icons. They are both confessions: the first by writing and hearing and the last by seeing. From a missionary point of view, the written evidence is equal to the hearing evidence. Making an analogy between the written facts and those described by images, the Church affirms that they both have the same aim: the speechless painting presents through imitation what the story presents through hearing.

The Holy Gospel is honoured for the process of hearing, which take the Word of God into our minds, and the icon is honoured because, by seeing, our minds overcomes materiality and the soul ascends to God. In the Eastern mysticism, the mind always ascends higher than the materiality, surpasses it through assumption, the same as the Holy Mysteries: the invisible grace is shared through visible elements (light, water, wine, bread, oil, etc.). In the process of deliverance, hearing is equal to seeing, and the sight is the sign of a circumscription (John, 20:29). Thus, the Studite doctrine of the icon, as well as the definition of faith by the Seventh Ecumenical Council of Nicaea $\left(13^{\text {th }}\right.$ of October 787) are illuminating:

"The iconic painting, as one in harmony with the story of the Gospel, is useful for the real, not imaginary, faith in the Incarnation of God the Word on our unanimous behalf; because, as two sides mirroring doubtless each other, they (the word and the icon) have obviously, the same availability" 27 .

\section{References:}

1. Basil the Great, Despre Sfântul Duh (On the Holy Spirit), rom. transl. by C. Cornițescu, T. Bodogae, [collection Părinți și Scriitori Bisericești, vol. 12], București, Institutul Biblic și de Misiune a

${ }^{26}$ Ibidem, p. 262.

27 The 'Oros' of $7^{\text {th }}$ Ecumenical Council (Nicaea), in Iisus Hristos Prototip al icoanei Sale, p. 193. 
Bisericii Ortodoxe Române, 1988.

2. GRIGORY OF NYSSA, "Epistola către fratele său, Petru: Despre diferența dintre ființă și ipostas”, ST. THEODORE THE STUDITE, in Iisus Hristos Prototip al icoanei Sale, rom. transl. by Ioan I. Ică jr., Alba Iulia, Deisis, 1994;

3. Grumel, Venance, "L'Iconologie de saint Théodore Studite", in Échos d'Orient, no.123/1921;

4. EMILIANOS SimONOPETRITUL, Cuvântări mistagogice la sărbători, rom. transl. by Agapie Corbu, Arad, Sfântul Nectarie, 2016;

5. ICĂ, I. Ioan jr., "Iconologia bizantină între politică imperială și sfințenie monahală", in ST. THEOdORE THE STUdite, Iisus Hristos Prototip al icoanei Sale, Alba Iulia, Deisis, 1994;

6. JUGIE, Martin, "La doctrine mariale de saint Théodore Studite", in Échos d'Orient, no. 144/1926;

7. NICHIFOR (The Patriarch), Antiretice, I; P. G. 100, 244 D;

8. TheOdORE THE StUdite, Cuvântări duhovnicești, rom. transl. Filaret al Râmnicului, Alba Iulia, Reîntregirea, 2016;

9. TheOdore the Studite, Iisus Hristos Prototip al icoanei Sale (The Treaties against the Iconomachs), rom. transl. By Ioan I. ICĂ jr., Alba Iulia, Deisis, 1994. 